University of Louisville

ThinkIR: The University of Louisville's Institutional Repository

Electronic Theses and Dissertations

8-2013

\title{
Plant and arthropod diversity in prairie restorations around Louisville, $\mathrm{KY}$.
}

Sarah Elizabeth Atherton

University of Louisville

Follow this and additional works at: https://ir.library.louisville.edu/etd

\section{Recommended Citation}

Atherton, Sarah Elizabeth, "Plant and arthropod diversity in prairie restorations around Louisville, KY." (2013). Electronic Theses and Dissertations. Paper 56.

https://doi.org/10.18297/etd/56

This Master's Thesis is brought to you for free and open access by ThinkIR: The University of Louisville's Institutional Repository. It has been accepted for inclusion in Electronic Theses and Dissertations by an authorized administrator of ThinkIR: The University of Louisville's Institutional Repository. This title appears here courtesy of the author, who has retained all other copyrights. For more information, please contact thinkir@louisville.edu. 
PLANT AND ARTHROPOD DIVERSITY IN PRAIRIE RESTORATIONS AROUND LOUISVILLE, KY

\author{
By \\ Sarah Elizabeth Atherton \\ B.S., Northern Kentucky University, 2010 \\ A Thesis \\ Submitted to the Faculty of the \\ College of Arts and Sciences of the University of Louisville \\ in Partial Fulfillment of the Requirements \\ for the Degree of \\ Master of Science \\ Department of Biology \\ University of Louisville \\ Louisville, Kentucky
}

August 2013 



\section{PLANT AND ARTHROPOD DIVERSITY IN PRAIRIE RESTORATIONS AROUND LOUISVILLE, KY \\ By \\ Sarah Elizabeth Atherton \\ B.S., Northern Kentucky University, 2010}

A Thesis Approved on

August 1, 2013

by the following Thesis Committee:

Dr. Perri Eason

Dr. Sarah Emery

Dr. Omar Attum 


\section{DEDICATION}

This dissertation is dedicated to my parents for encouraging me in whatever I wanted to do and for always letting me explore the world around me, barefoot and curious. 


\section{ACKNOWLEDGEMENTS}

I would like to thank first and foremost, my major professor, Dr. Perri Eason, for her unerring support and guidance in this project and beyond. I would also like to thank my committee members, Dr. Sarah Emery and Dr. Omar Attum, for their input and assistance with my project and writing. I would like to thank Jeff Masters for helping me with arthropod and plant identification as well as Dr. Tim Phillips at the University of Kentucky for helping me with plant identification. I would also like to thank my husband, Willie Atherton for his patience and support during the whole process and for putting up with ticks and bags of bugs in our freezer. Thank you to Mark and Denise Bentley for helping acquire and cut multiple materials for traps, and for the freezer space. Thanks to my parents Jim Eagleson, Linda Eiden, Steve Davis, and Donna Caudill for the financial and emotional support. Thank you to Ryan Skees, Aaron Bischoff, Sarah Ramaker, and Carl Cloyed for helping dig holes in the heat of summer and Elizabeth Seng and Brad Welsh for going out and helping me collect. 


\section{ABSTRACT \\ PLANT AND ARTHROPOD DIVERSITY IN PRAIRIE RESTORATIONS AROUND LOUISVILLE, KY}

SARAH E. ATHERTON

AUGUST 1, 2013

Prairies are important ecological biomes that contain high biodiversity of economic and ecologically important flora and fauna. Unfortunately, despite the vast historic distribution over most of mid-America, remnant prairies are critically threatened due to urbanization and other anthropogenic activities. Therefore, measurements of richness are utilized to assess the stability and condition of remnant and restored prairies - higher richness indicating greater ecosystem stability. Arthropod abundance comprises a significant portion of the species richness found in prairies. Because of this, arthropods are an ideal group of organisms to study due to their relatively limited dispersal range and utilization of microhabitats. In this study, arthropods were collected in the summer of 2012 at four restored prairies located in Jefferson (Iroquois Park and American Synthetic Rubber Company Landfill), Nelson (Jefferson Memorial Forest), and Bullitt (Bernheim Research Forest and Arboretum) Counties of Kentucky. Comparisons of species richness for arthropods and vegetation were made between study locations. Because of low sample sizes and species dominance, no definitive relationships were determined. However, information about plant and arthropod presences were compiled for site management reference. 


\section{TABLE OF CONTENTS}

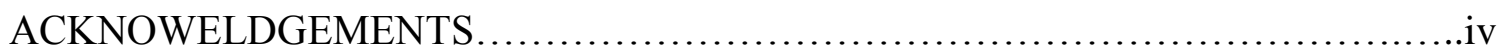

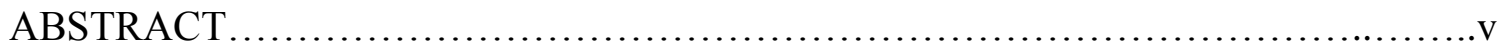

LIST OF FIGURES....................................................vii

LIST OF TABLES...........................................................

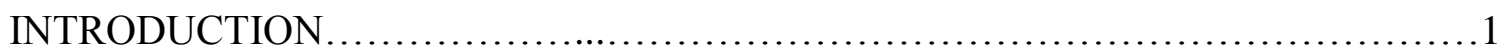

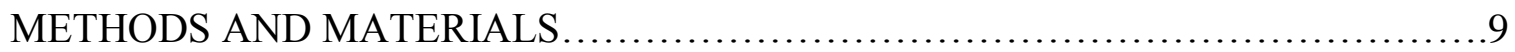

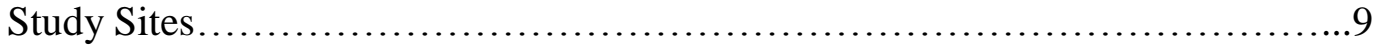

Vegetation Survey................................................10

Arthropod Sampling.................................................11

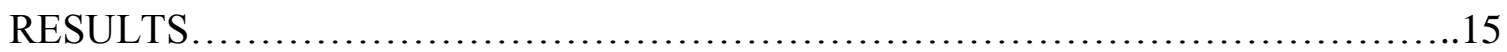

General............................................................. 15

Plant vs Plant Relationships............................................ 15

Plant vs Arthropod Relationships.....................................16

Arthropod vs Arthropod Relationship..................................... 16

Tables and Figures................................................... 18

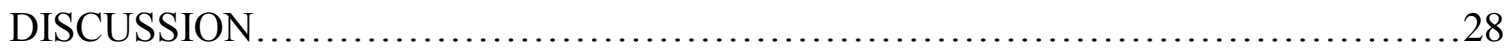

REFERENCES........................................................ 37

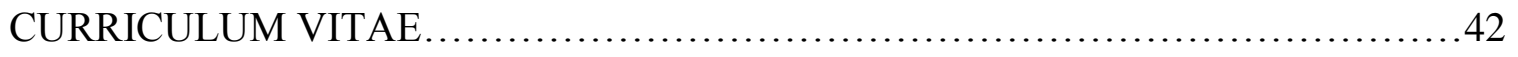




\section{LIST OF FIGURES}

\section{FIGURE}

1. Proportion of vegetative cover of plant functional groups, Part 1

2. Proportion of vegetative cover of plant functional groups, Part 2

3. Plant mass by study site

4. Proportion of soil cover by study site

5. Plant species diversity and arthropod functional group diversity

6. Arthropod abundance by site

7. Arthropod abundance by functional group, Part 1

8. Arthropod abundance by functional group, Part 2

9. Proportion of predators, sap suckers, herbivores, and parasitoids by site

10. Total arthropod abundance vs arthropod family diversity 


\section{LIST OF TABLES}

\section{TABLE}

1. A summary of site attributes

2. Plant richness, diversity, and evenness results

3. Top 10 plant species proportions by study site

4. Plant species retained from original seeding

5. Top 10 arthropod group abundance by study site

6. Arthropod richness diversity, and evenness results 


\section{INTRODUCTION}

\section{BACKGROUND}

The Great Plains is a critically threatened biome in the United States that once lay across the middle third of the US, stretching from the Rocky Mountains to the eastern edge of North Dakota down into Texas, totaling an estimated 162 million hectares (Samson and Knopf 1994). Today, native prairie habitat is threatened by urbanization, agriculture, suppressed natural fires, habitat fragmentation, and elimination of native ungulates so that an estimated $85-98 \%$ or more of the historical prairies in the United States have been destroyed (Howe 1994).

Prairie habitats play a crucial role as an ecosystem on the planet. Extensive human disturbances such as conversion to agriculture severely decrease biodiversity often consisting of a few common species in the place of many rare (McKinney and Lockwood 1999). Not only does agriculture decrease biodiversity, it reduces the natural system to prevent erosion in what is generally a wind-swept, higher drought-risk ecosystem. Grasslands have been found to significantly reduce soil runoff and erosion better than agricultural areas including corn fields (Kateb et al. 2013). The severe reduction of grasslands and the increase of poor agricultural practices, which were exacerbated by drought, caused the Dust Bowl in the 1930s (Porter 2012). The absence of grasslands caused substantial ecological and economical damage. Due to the severe reduction and the importance of grasslands, attempts at restoration of these areas are widespread. 
Restoration of grasslands is an important, yet expensive and arduous process. However, the execution of the restorations is extremely varied and while there is communication among practitioners, there is no conclusive decision on the most effective means of restoration execution (Rowe 2010). Management techniques include fire, mowing, and livestock grazing, although there are many different schools of thought concerning the timing and execution of these methods (Morris 2000, Panzer 2002). Even the length of time that it takes a restoration to resemble a remnant is disputed, some believing that the site can be restored in 7-10 years (Summerville et al. 2007) while others believe it will take centuries (Sampson and Knopf 1994). For this reason, age alone is not a reliable indicator of restoration success. One must consider management, proximity of other suitable habitat for species dispersal, and several other factors. Unfortunately, the few remnant prairies that are left are declining in quality due to small patch size, edge effects, invasive species, and the surrounding matrix (Koper et al. 2010). Due to the lack of knowledge about prairie restoration, it is vital to assess the success of a restoration project during and after restoration. Plant diversity is commonly used as a method of ecosystem evaluation, whether for restoration assessment or for assessing the impact of a particular disturbance (Martin et al. 2005, Gusmeroli et al. 2013, Kershaw and Mallik 2013). Arthropods are also used for this purpose (Brand and Dunn 1998, Jonas et al. 2002, Hartley et al. 2007). Therefore, assessment of restoration success can be assisted by comparing plant and arthropod diversity in a variety of restored sites in order to determine the relationship between arthropod and plant diversity. This information can be used to help make restoration decisions such as what plant species are important and should be included in seed mixes. 
Native prairies have high biodiversity and species richness of both plants and animals. In fact, a literature survey completed by Wilson et al., 2012, found that at the smaller plot scale used to account for varying biome size, temperate grasslands contain higher species richness than tropical rainforests, which are famously diverse.

Traditionally, tallgrass prairies are thought of as being dominated by a few key warm-season $\mathrm{C}_{4}$ species such as Andropogon gerardii (Big Bluestem), Panicum virgatum (Switchgrass), Sorghastrum nutans (Yellow Indiangrass), and Schizachyrium scoparium (Little Bluestem), as well as many forbs in the Lamiaceae (Mint) and Asteraceae (Sunflower) families (Howe 1994, Silletti et al. 2004). A high quality prairie also has a large abundance of sedges and is inhabited by hemiparasites (Howe 1994, Sivicek and Taft 2011). However, because there is no correlation between these dominant species and the presence of rarer species, the presence of these dominants does not indicate the health of a prairie or the success of a restoration (Howe 1994). There is general agreement that high plant diversity should be a goal of prairie restoration and management, in part because as the diversity of plant species (Tilman 1997, Tilman and Downing 1994) or plant functional groups (Pokorny et al. 2005) increases, the resistance of the ecosystem also increases, making it less likely that non-native species will be able to invade it. Additionally, high native plant species diversity greatly increases the productivity of an ecosystem (Tilman et al. 2012).

Despite that agreement, it is well documented that plant species richness is lower in restored than in remnant prairies (Kindscher and Tieszen 1998, Sluis 2002). Unfortunately, many seed mixes used in prairie restorations are severely lacking in species and functional group diversity and richness (Sivicek and Taft 2011). There are 
many possible reasons for this; seeds for some groups, for example sedges and $\mathrm{C}_{3}$ grasses, are either included in concentrations too low to be effective or omitted altogether due to high cost and a low likelihood of successful establishment. Similarly, the diversity of important groups such as forbs is low compared to the diversity seen in remnant prairies. As a result, the seed mixes used for restorations are overly rich in groups such as C4 grasses, which establish dominance quickly and completely in the restoration site (Rowe 2010). An additional difficulty encountered by restorers is that even if highly diverse seed mixes are used, many of those species may not be able to establish, possibly resulting in decreasing diversity as the plot ages and other plant species become dominant (Sluis 2002).

In addition, restored prairie sites commonly contain a considerably higher proportion of exotic plant biomass as well as a greater number of exotic plant species than their remnant counterparts (Martin et al. 2005). As the abundance of exotic species increase, biodiversity of the restored sites can decrease rapidly (Wilsey et al. 2009). Not all exotic species affect ecosystems at the same magnitude. A study by Larson and Larson 2010, found that when comparing exotic forbs and grasses, grasses had a more detrimental effect on native plant species diversity and biomass. One of the most abundant and prolific exotic grasses to invade restored prairies is Sorghum halepense, or Johnson grass. Johnson grass not only has high fecundity, but also can grow clonally via rhizomes. Additionally, Johnson grass chemically outcompetes native species via production of secondary defensive chemicals against herbivory and allelopathy. In addition, the plant's more rapid growth, greater height, and larger biomass than native species effectively blocks light from reaching native species. This aggressive species can 
quickly turn a burgeoning, diverse prairie restoration into a virtual monoculture (Rout et al. 2013).

Finally, the matrix surrounding a restored prairie can also have strong effects on its success. For example, there is a much higher rate of plant species extinction in urban restored prairies compared to rural ones (Williams et al. 2005). Interestingly, although in most areas rare species are the most likely to become extinct, there can be an almost equal chance of extinction of rare and common species in urban areas due to the higher incidence of disturbance incurred in these areas (Williams et al. 2005). An intermediate amount of disturbance is considered to produce the highest amount of biodiversity for plants and animals (Wilkinson 1999). With too little disturbance, a limited number of species can dominate by competitive exclusion. With too great a disturbance, species will not have the ability to recolonize the area. Unfortunately, in urban areas, the disturbance is too great for many species to recover.

Another reason why higher diversity of plants is preferred in prairie restorations is that higher plant diversity is expected to result in higher animal diversity. Accordingly, in addition to measuring the success of restored prairies through their plant diversity, restoration ecologists have also examined animal diversity, often with a focus on arthropods. Arthropods are an ideal group of animals with which to determine the health of an ecosystem because of their abundance, diversity, and ubiquity. Assessments of prairie diversity often focus on members of the suborder Auchenorrhyncha, which includes leafhoppers, spittlebugs, and plant hoppers. These insects are an immensely important group due to their large abundance and diversity, and their role as a main prey item for many predators found in prairies (Nemec and Bragg 2008, Wallner et al. 2013, 
Rowe and Holland 2013). Several other arthropod groups have also been identified as particularly useful indicators for plant diversity and functional group richness. These groups include Orthoptera (Joern 1982, Bomar 2001, Nemec and Bragg 2008, Déri et al. 2011), beetles in the families Dermestidae (Looney et al. 2009) and Carabidae (Déri et al. 2011), Lepidoptera (Summerville 2008), Apidae (Öckinger and Smith 2006), and spiders in the family Nesticidae (Déri et al. 2011).

In native prairies, higher plant species richness was found to support higher arthropod species richness (Joern 1982, Panzer and Schwartz 1998, Jonas et al. 2002). The positive relationship between plants and arthropods can be attributed to a variety of factors. More structurally complex grasslands, which tend to be those with higher plant diversity support a higher number of insect species (Dennis et al. 1998). From the arthropods' perspective, an increase in plant diversity is likely to result in an increase in microhabitats, presence of novel oviposition sites, more options of food resources, and a greater number and diversity of refuges from predators (Joern 1982). These results are supported by various experimental tests. Siemann et al. 1998 and Haddad et al. 2001 agree that high plant species, and possibly functional group richness, correlates with high arthropod diversity, primarily due to increased structural diversity. Insect abundance also increased with plant species richness, contributing to the overall productivity of the system (Haddad et al. 2001). Some researchers believe that plant functional group diversity is more important than plant species richness as a determinant of arthropod diversity because plant functional group diversity has a greater impact on plant productivity and light penetration due to differing plant structure, thus affecting the diversity of microhabitats (Tilman et. al 1997). These effects are part of a "bottom-up" 
control in the prairie ecosystem that supports higher arthropod abundance of not only the herbivores and other prey groups, but also predators and parasites because prey are more difficult to locate in dense foliage and because the grasses provide a food source for adult parasites (Hunter and Price 1992). Contrarily, Siemann et al. 1998 mentioned that because many herbivores are specialists, an increase in plant species richness may not necessarily increase herbivore abundance due to increased difficulty of finding palatable plants in a more diverse landscape.

The effects of urbanization on arthropod groups have been well studied. Arthropods are a superiorly adaptive group of organisms that have been able to make use of the habitat heterogeneity provided by humans in cities, neighborhoods, etc., resulting in much higher levels of diversity than would be expected (Frankie and Ehler 1978). In fact, many groups of Diptera such as mosquitos and fruit flies have flourished in the new environment created by humans (Frankie and Ehler 1978). In urban prairies however, many groups of arthropods including springtails (Brand and Dunn 1998), ground beetles (Hartley et al. 2007), and woodlice (Souty-Grosset et al. 2005) are negatively affected by urbanization, with considerably higher diversity in undisturbed areas and remnant prairies compared to restored areas. This could be due to reduced food sources or elimination of suitable habitat (Brand and Dunn 1998, Souty-Grosset et al. 2005, Hartley et al. 2007). Some believe that these urban prairies will never be a true prairie because of their position as isolated islands in the urban matrix effectively eliminating natural insect colonization (Bomar 2001).

In this study, I will compare four prairie restorations to investigate differences in plant and arthropod diversity and abundances. Studies have shown a relationship between 
plant diversity and arthropod diversity, so I compared levels of diversity of each group at the species, family, and functional group levels (Joern 1982 and Panzer, Tilman et. al 1997, Schwartz 1998, Haddad et al. 2001). Because plant diversity has been shown to increase productivity, I investigated that relationship as well. Lastly, the relative abundances of different functional groups of arthropods were compared to find if the arthropod communities resembled those analyzed in a landmark by Tilman et al. 1998. I expected to find a positive relationship between plant diversity and arthropod diversity, as well as productivity. 


\section{METHODS}

\section{STUDY SITES}

In order to investigate the relationships of site boundaries and plant diversity on arthropod diversity, arthropods were collected from four restored prairie sites in Kentucky. The sites were of varying age, size and surroundings. Scott's Gap at Jefferson Memorial Forest (JMF) is a suburban, 12-year-old, restored farmland site covering 2.8 hectares at an elevation of $160 \mathrm{~m}$. The site is managed by fire every two to three years. In mid-July, the vegetation was approximately $2 \mathrm{~m}$ tall. The newest site is an urban Landfill that is currently in the process of restoration by Redwing Ecological Services, INC. Data were collected from seven replicate plots on the Landfill site, totaling around 6.9 hectares. The elevation of the Landfill site is $137 \mathrm{~m}$, and it is managed by mowing and herbicide to remove non-native species. In mid-July, the vegetation was approximately 1.5m tall. Golden Eagle Ridge at Bernheim Research Forest and Arboretum is an 8-yearold, rural site which was restored from farmland. The site is a 9.3 hectare prairie which is burned every two to three years with mowing during the off years and is at an elevation of $164 \mathrm{~m}$. In mid-July, the vegetation was approximately $1 \mathrm{~m}$. The study site at Iroquois Park is an 18-year-old restoration with an elevation of $230 \mathrm{~m}$. This site is 5.7 hectares and is burned roughly every two to three years with mowing on the off years. In mid-July, the vegetation was approximately $.7 \mathrm{~m}$ tall. This site information is expanded in Table 1. 


\section{VEGETATION SURVEY}

I identified 60 plant species which I separated into 8 functional groups: Cool Season Grasses, Forbs, Legumes, Warm Season Grasses, Shrubs, Trees, and Sedges and Rushes. These groups were chosen due to their morphological and physiological characteristics as well as their varying roles in a prairie ecosystem as host plants for herbivores and also as their role in creating microhabitats for the animals that live in prairies (Symstad 2002). Grasses and forbs are the dominant groups in prairies (Howe 1994, Silletti et al. 2004), and legumes are important in restorations due to their ability to fix nitrogen, often a limiting resource in prairie restorations (Tilman et al. 1997).

Vegetation surveys were conducted once at each study site during the arthropod collection period. Plants were identified in $121 \mathrm{~m}^{2}$ blocks at JMF, Bernheim, and Iroquois, within the $5 \mathrm{~m}^{2}$ area between pitfall traps. At the Landfill, in each of the seven sections, plants were identified in two $1 \mathrm{~m}^{2}$ blocks, in the area between pitfall traps. In each of these blocks, the proportion of cover of each plant species was determined using the Daubenmire Scale (Daubenmire 1959). To use the Daubenmire Scale, a frame is made and placed in the area to be examined. As viewed from above, the canopy cover of each species within the frame are estimated into one of six cover classes, covering $0-5 \%$, $5-25 \%, 25-50 \%, 50-75 \%, 75-95 \%$, or $95-100 \%$ of the area. Using these cover classes, I was able to calculate the proportion of each plant species per site which was used to calculate the Shannon-Wiener Diversity Index (H') as well as the Pielou's Evenness Index ( $\left.\mathrm{J}^{\prime}\right)$ of both species and functional groups. For this study, I omitted the proportions from each site that were bare ground as it would not add to species richness. The plant data collected were also used to calculate plant species and functional group richness. 
Additionally, to obtain a measure of productivity, I collected plant material from a $10 \mathrm{~cm}^{2}$ area within each block. I then dried these plants at $30^{\circ} \mathrm{C}$ for 48 hours and then I weighed their total mass.

To measure climate variation among study sites, using a min-max thermometer, I measured minimum and maximum temperatures collected over the three-day, two-night periods during which the pitfall traps were open. Additionally, relative humidity readings were taken using a Taylor 9- inch Sling Psychrometer on the day sweep-netting was performed.

I statistically compared plant species and functional group richness, diversity, and evenness, as well as arthropod family and functional group richness, diversity, and evenness using the Pearson Bivariate Correlation Analysis on SPSS at the site scale (IBM Corp. 2012).

\section{ARTHROPOD SAMPLING}

Arthropods were sampled from April-July of 2012 to capture diversity changes following plant phenology. I used pitfall traps to collect ground-dwelling arthropods and sweep-netting to collect arthropods in the vegetation. Pitfall trap cups measured $8.2 \mathrm{~cm}$ in diameter and were $11.4 \mathrm{~cm}$ deep. To reduce the escape of the arthropods that fell into the traps, the cups contained $2.5 \mathrm{~cm}$ of water with a drop of dish soap to break the surface tension and an inch of a petroleum jelly/mineral oil mixture around the rim of the cup. Propylene glycol was not used because of its attractiveness to larger animals such as mammals and birds. To prevent theft of arthropods from the traps by predators, I covered each pitfall trap with a $16.3 \times 16.3 \times 1.3 \mathrm{~cm}$ square of plywood. Each square had legs on the corners and sat $5 \mathrm{~cm}$ above the pitfall trap. At JMF, Bernheim, and Iroquois, 21 pitfall 
traps were arranged in a grid of three by seven, with five meters between neighboring traps. At the restored Landfill, in each of the seven sections, 3 pitfall traps were arranged in a straight transect, again with five meter spacing, totaling 21 traps. For all sites, traps were placed at least $20 \mathrm{~m}$ from the prairies' edges to reduce any edge effects. In all four study sites, traps were left out three days and two nights bi-weekly. I removed arthropods from the water each day using tweezers and then placed them in whirl-twist bags with $80 \%$ alcohol.

Sweep-net collections were performed using a $38 \mathrm{~cm}$ in diameter net along $20 \mathrm{~m}$ transects. Along each transect, 40 steps were taken with a complete figure eight sweep every two steps. At JMF, Bernheim, and Iroquois, samples from seven $20 \mathrm{~m}$ transects were collected. At the Landfill, in each of the seven sections, samples from a single $20 \mathrm{~m}$ transect were collected. Each sample from a sweep-net transect on a given date was placed in a separate gallon-sized zip-lock bag and frozen for later analysis. Books which assisted in arthropod identification were Insects and Their Natural History and Diversity by Stephen A. Marshall (2006) and Spiders of North America by D. Ubick et al. (2005).

I identified the arthropods into 81 families plus the orders Diptera and Isoptera. Dipterans, hymenopterans, and arachnids smaller than $2 \mathrm{~mm}$ were classified as microdiptera, microhymenoptera, and microarachnids and orthopterans smaller than $4 \mathrm{~cm}$ were classified as microorthoptera. I divided these arthropods into 11 functional groups: Detritivores, Fungivores, Generalists, Granivores, Herbivores, Nectivores, Parasites, Parasitoids, Predators, Sap Suckers, and Scavengers. These groups were selected because they fully encompass the life history strategies of all the arthropods collected and highlight the different trophic levels of the prairie arthropods. 
The orders and families included in these functional groups are as follows:

1. Detritivore: Feeds on decaying plants and animal fecal matter.

Blattaria (Blattidae), Collembola, Coleoptera (Mordellidae, Silphidae), Opiliones

(Phalangidae), Polydesmida (Polydesmidae), Orthoptera (Gryllidae,

Rhaphidophoridae), and Spirobolida (Spirobolidae), Isopoda.

2. Fungivore: Feeds on fungi.

Coleoptera (Erotylidae, Leiodidae, Pyrochoridae, Sphindidae).

3. Generalist: Feeds on a variety of foods.

Diptera, Microdiptera, Hymenoptera (Formicidae), and Coleoptera

(Tenebrionidae).

4. Granivore: Feeds on seeds and grains of plants.

Coleoptera (Bruchidae) and Hemiptera (Lygaeidae, Pyrrhocoridae).

5. Herbivore: Feed on plant matter such as leaves.

Orthoptera (Acrididae, Tetrigidae), Coleoptera (Chrysomelidae, Cocinellidae,

Elateridae, Scarabidae, Thyreocoridae), Hemiptera (Coreidae, Pentatomidae), and

Microorthoptera.

6. Nectivore: Feed on flower nectar and pollen.

Lepidoptera (Alucitidae, Arctiidae, Lasiocampidae, Lycaenidae, Noctuidae, Tortricidae), Hymenoptera (Apidae, Halictidae), and Neuroptera (Chrysopidae).

7. Parasite: Feed on blood as a parasite.

Ixodida (Argasidae, Ixodidae).

8. Parasitoid: Adults lay eggs in the larvae of other arthropods which hatch and eat the larvae alive. 
Hymenoptera (Braconidae, Cynipidae, Ichneumonidae) and microhymenoptera.

9. Predator: Feeds on other arthropods.

Coleoptera (Anthicidae, Anthocoridae, Cantharidae, Carabidae, Cicindelidae, Lampyridae, Staphylinidae), Araneae (Anyphaenidae, Araneidae, Linyphiidae, Lycosidae, Oxyopidae, Philodromidae, Salticidae, Tetragnathidae, Tomisidae), Microaracnid, Odonata (Coenagrionidae), Hemiptera (Geocoridae, Nabidae, Reduviidae), Geophilomorpha (Geophilidae), Mantodea (Mantidae), Neuroptera (Myrmeleontidae), Scutigeromorpha (Scutigeridae), Hymenoptera (Vespidae).

10. Sap Sucker: Feed on the phloem of plants.

Hemiptera (Issidae, Aphididae, Cercopidae, Cicadellidae, Cydnidae, Delphacidae, Dictyopharidae Membracidae, Miridae, Pachygronthidae, Tingidae) and Coleoptera (Buprestidae, Curculionidae).

In order to evaluate the arthropods collected, I counted arthropod family and functional group richness and calculated the Shannon-Wiener Diversity Index $\left(\mathrm{H}^{\prime}\right)$ as well as the Pielou's Evenness Index $\left(\mathrm{J}^{\prime}\right)$ of those measures at the site level. Total abundance of each family and functional group found at each site were counted and were converted to proportions in order to find any trends in abundances of particular groups. I also investigated the abundances of particular functional groups to determine if there was a relationship with either plant or arthropod diversity. 


\section{RESULTS}

\section{GENERAL}

Over the collection period, 11,270 total arthropods were collected and across the four sites, I identified 60 different plant species. Of the 60 plant species, $68 \%$ were native to Kentucky, $22 \%$ were invasive, and $10 \%$ were not possible to identify to species.

\section{PLANT VS PLANT INTERACTIONS}

There was considerable variation across the sites in the presence and dominance of plant species and functional groups. As seen on Table 2, Iroquois contained the highest plant species richness and diversity while JMF contained the lowest plant diversity. Bernheim contained the highest functional group diversity and evenness. In terms of functional group, Iroquois and JMF were the only sites to have rushes and sedges and Bernheim had a considerably higher proportion of cool season grasses than any other site (Fig.1). Bernheim also had the highest proportion of legumes and shrubs and the lowest proportion of warm season grasses (Fig. 2). Contrarily, the Landfill and JMF were dominated by warm season grasses. Due to the typical large height and biomass of warm season grasses, it is not surprising that JMF and the Landfill had the largest biomass collected from the sites (Fig. 3). Iroquois is the only site that is dominated by a native species, Helicanthus mollis. JMF and the Landfill are dominated by invasive Sorghum halpense and Bernheim is dominated by invasive legume Lespedeza cuneata. Iroquois also had the highest proportion of native species as well as the highest proportion of native plant cover. The Landfill had the lowest proportion of native species and the 
lowest cover of native species. A complete list of the top 10 plant species found at each site can be found in Table 3. Few species in each site were retained from original seeding lists as seen in Table 4. Iroquois retained the highest number of species seeded. JMF had only two species retained, which is most likely partially due to the dominance of Johnson grass. The Landfill retained four species, which is low considering the site is only two years old.

When I used the Daubenmire Scale to calculate plant cover, soil cover was included in the collection. However, because the proportion of soil cover does not contribute to the plant species richness, calculations were performed only on the plants present, without the proportion of soil included. Not surprisingly, the Landfill had a considerable higher proportion of soil relative to the other study sites and Iroquois had the lowest proportion (Fig 4).

\section{PLANT VS ARTHROPOD INTERACTIONS}

There was a significant negative correlation between plant species diversity and arthropod functional group diversity ( $\mathrm{p}=0.05$ ) (Fig. 5).

\section{ARTHROPODS}

When pooling arthropod abundances by site, the abundance of arthropods at the Landfill was considerably higher than at the other study sites, primarily due to a large abundance of particular groups such as isopods, generalists, and sap suckers (Fig. 6). A complete list of the top 10 arthropod groups per site can be found in Table 5. The highest abundance arthropod group at JMF was Cicadellidae and Microdiptera, together constituting almost $29 \%$ of the arthropod abundance. The Landfill was dominated by 
isopods (36.4\%) and Bernheim and Iroquois had high abundances of formicidae (23.2\% and $35.9 \%$, respectively).

Despite the discrepancy in arthropod abundance between sites, when I compared the proportion of functional groups, the sites were similar except that the Landfill had a much higher abundance of detritivores (Fig. 7) and JMF had a higher proportion of parasites (Fig. 8). Some functional groups were not represented at every site. For example, scavengers were only found at Bernheim and JMF, and granivores were only found at Bernheim and the Landfill.

When I compared the proportions of predators, herbivores, and sap suckers, the proportions of each functional group were similar across study sites, with Bernheim supporting a slightly higher proportion of predators, but a lower proportion of herbivores (Fig. 9). I chose these groups of arthropods to compare due to suggestions from Siemann et al. 1998 that predators have a much larger impact on the abundance of prey species, such as herbivores and sap suckers than do the plant species. Across sites, as arthropod abundance increased, arthropod family diversity decreased (p=.012) (Fig. 10). Arthropod family diversity varied across sites, with JMF having the highest diversity and Iroquois and the Landfill with the lowest. I discovered that despite the high arthropod family richness found at Iroquois, high abundances of Cicadellidae, Diptera, and microdiptera decreased the family evenness, causing it to have almost the lowest diversity. A complete list of arthropod richness, diversity, and evenness can be found in Table 6. 


\section{TABLES AND FIGURES}

\begin{tabular}{|c|c|c|c|c|}
\hline & JMF & Landfill & Bernheim & Iroquois \\
\hline $\begin{array}{l}\text { Age of } \\
\text { Restoration } \\
\text { (Years) }\end{array}$ & 12 & 2 & 8 & 18 \\
\hline Size (ha) & 2.8 & 6.9 & 9.3 & 5.7 \\
\hline Surroundings & Suburban & Urban & Rural & Urban \\
\hline Management & Spring Burning & $\begin{array}{l}\text { Mowing and } \\
\text { Herbiciding } \\
\text { (Imazapic) }\end{array}$ & $\begin{array}{l}\text { Spring Burning } \\
\text { and Mowing }\end{array}$ & $\begin{array}{l}\text { Spring Burning } \\
\text { and Mowing }\end{array}$ \\
\hline $\begin{array}{l}\text { Pre-restoration } \\
\text { Use }\end{array}$ & Farmland & Landfill & Farmland & $\begin{array}{c}\text { Unplanted } \\
\text { Grasses }\end{array}$ \\
\hline Elevation (m) & 160 & 137 & 164 & 230 \\
\hline $\begin{array}{l}\text { Latitude and } \\
\text { Longitude }\end{array}$ & $\begin{array}{l}38^{\circ} 03 ' 29.40^{\prime \prime} \mathrm{N} \\
85^{\circ} 50 ' 35.39^{\prime \prime} \mathrm{W}\end{array}$ & $\begin{array}{l}38^{\circ} 12^{\prime} 23.77^{\prime \prime} \mathrm{N} \\
85^{\circ} 50^{\prime} 31.28^{\prime \prime} \mathrm{W}\end{array}$ & $\begin{array}{l}37^{\circ} 52^{\prime} 06.57^{\prime \prime} \mathrm{N} \\
85^{\circ} 36^{\prime} 41.02^{\prime \prime} \mathrm{W}\end{array}$ & $\begin{array}{l}38^{\circ} 09^{\prime} 42.13 ” \mathrm{~N} \\
85^{\circ} 47^{\prime} 15.79^{\prime \prime} \mathrm{W}\end{array}$ \\
\hline
\end{tabular}

Table 1. A summary of study site attributes.

\begin{tabular}{|l|c|c|c|c|}
\hline & JMF & Landfill & Bernheim & Iroquois \\
\hline Plant Species Richness & 17 & 17 & 17 & 27 \\
\hline Plant Species Diversity & 1.116 & 1.350 & 1.521 & 1.841 \\
\hline Plant Species Evenness & 0.394 & 0.487 & 0.537 & 0.572 \\
\hline $\begin{array}{l}\text { Plant Functional Group } \\
\text { Diversity }\end{array}$ & 0.724 & 0.571 & 1.306 & 0.757 \\
\hline $\begin{array}{l}\text { Plant Functional Group } \\
\text { Evenness }\end{array}$ & 0.523 & 0.412 & 0.729 & 0.422 \\
\hline
\end{tabular}

Table 2. Plant richness, diversity, and evenness results. 


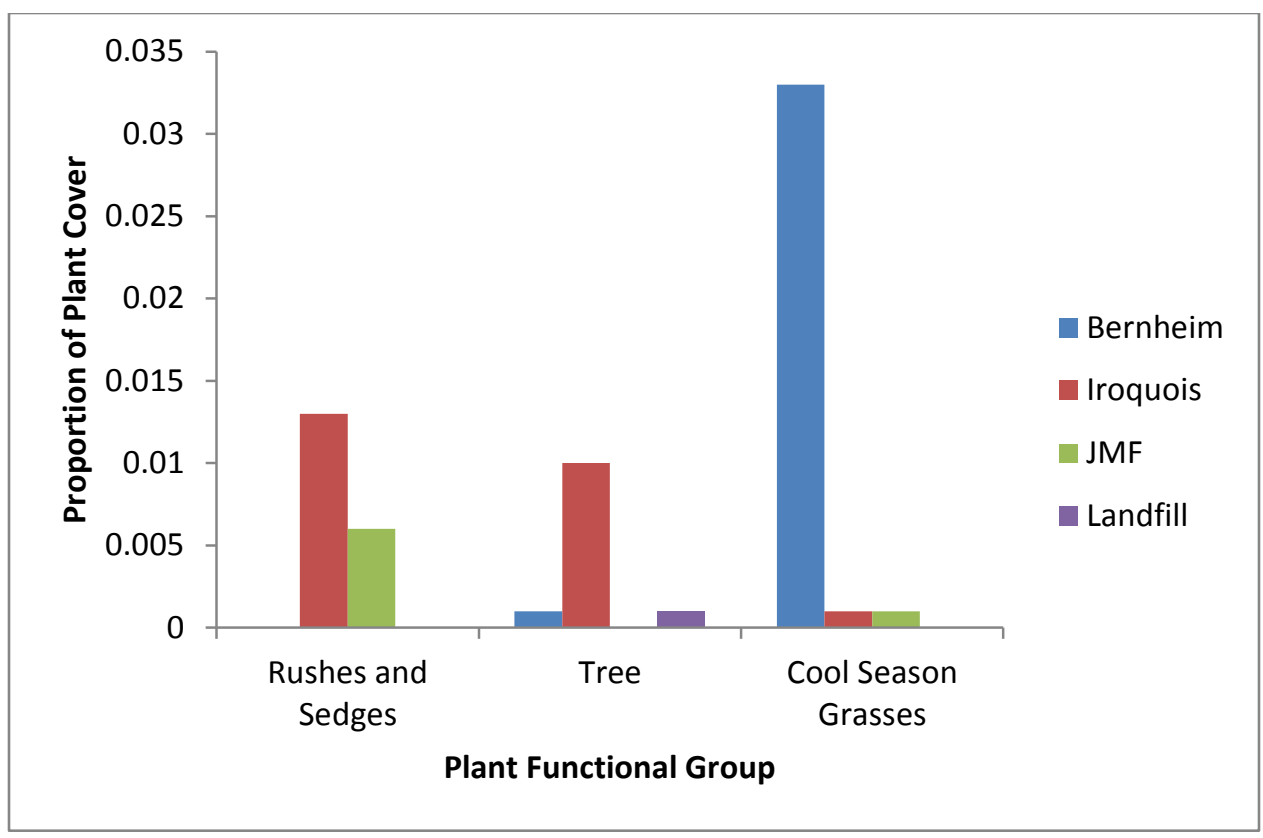

Fig. 1. Proportion of plant cover by functional group, part 1.

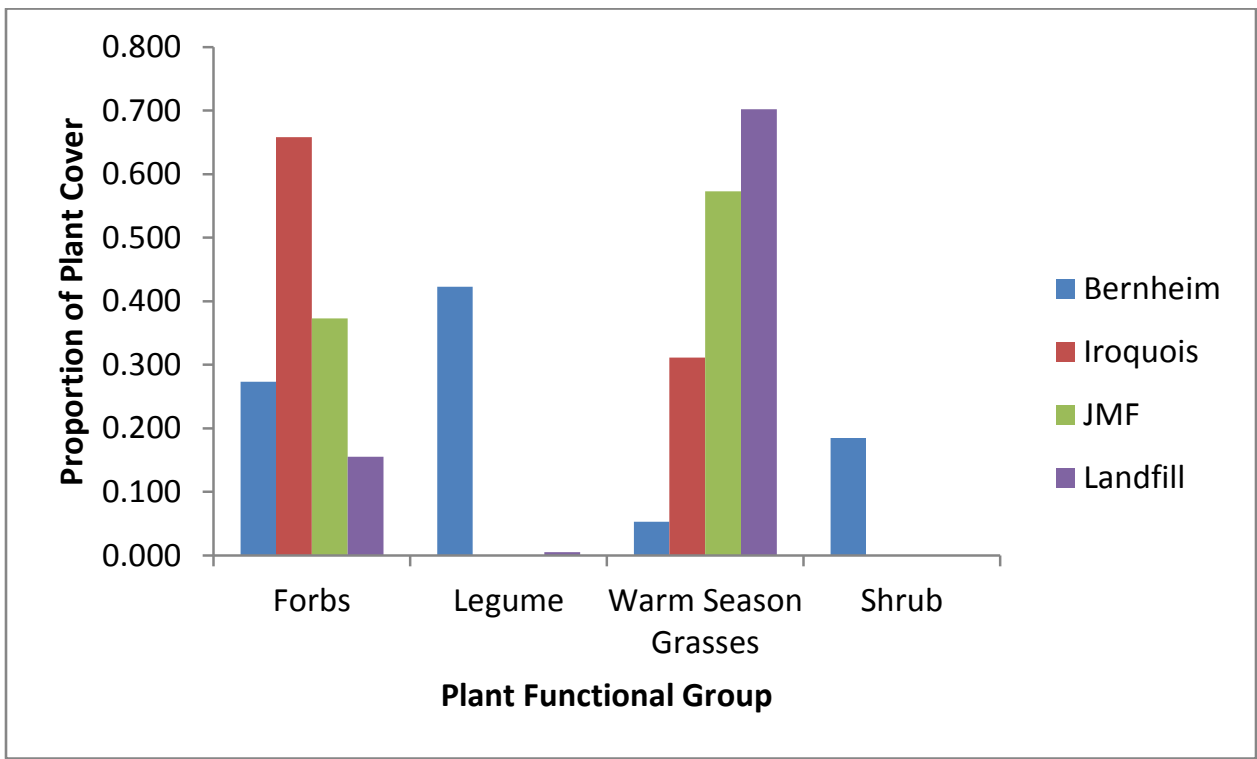

Fig. 2. Proportion of plant cover by functional group, part 2. 


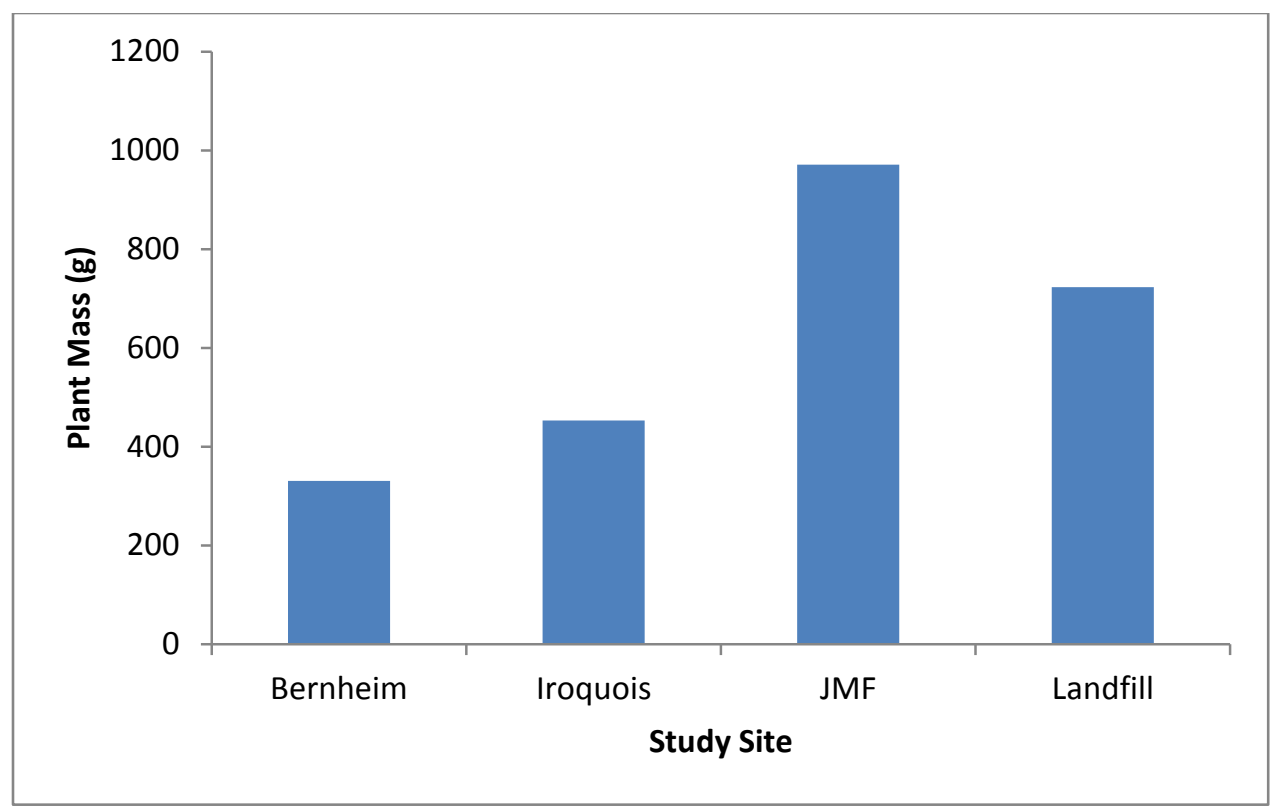

Fig. 3. Plant mass by study site. JMF and the Landfill had the highest plant mass most likely because they are dominated by prolific warm season grasses. 


\begin{tabular}{|c|c|c|c|c|c|c|c|c|c|}
\hline & & \multicolumn{2}{|c|}{$\mathrm{JMF}$} & \multicolumn{2}{|c|}{ Landfill } & \multicolumn{2}{|c|}{ Bernheim } & \multicolumn{2}{|c|}{ Iroquois } \\
\hline Species & Status & $\begin{array}{c}\% \\
\text { Cover }\end{array}$ & Rank & $\begin{array}{c}\% \\
\text { Cover }\end{array}$ & Rank & $\begin{array}{c}\% \\
\text { Cover }\end{array}$ & Rank & $\begin{array}{c}\% \\
\text { Cover }\end{array}$ & Rank \\
\hline Johnson Grass & Invasive & 0.572 & 1 & 0.523 & 1 & 0.016 & 7 & - & - \\
\hline Tall Goldenrod & Native & 0.270 & 2 & - & - & 0.234 & 2 & 0.053 & 4 \\
\hline Common Ragweed & Native & $\mathbf{0 . 0 3 7}$ & 3 & 0.004 & 9 & 0.009 & 8 & - & - \\
\hline White Thoroughwort & Native & 0.024 & 4 & - & - & - & - & - & - \\
\hline Rattlesnake Master & Native & 0.023 & 5 & - & - & - & - & - & - \\
\hline Common Threeseed Mercury & Native & 0.008 & 6 & - & - & - & - & - & - \\
\hline Ironweed & Native & 0.007 & 7 & 0.000 & 17 & 0.001 & 17 & - & - \\
\hline Frank's Sedge & Native & 0.006 & 8 & - & - & - & - & - & - \\
\hline Panicled Tick-Trefoil & Native & 0.001 & 9 & - & - & 0.017 & 6 & 0.001 & 19 \\
\hline Curly Dock & Invasive & 0.001 & $\mathbf{1 0}$ & 0.074 & 3 & 0.001 & 14 & - & - \\
\hline Switchgrass & Native & - & - & 0.103 & 2 & 0.009 & $\mathbf{1 0}$ & - & - \\
\hline Hairy White Oldfield Aster & Native & - & - & 0.044 & 4 & - & - & 0.007 & 13 \\
\hline Big Bluestem & Native & - & - & $\mathbf{0 . 0 3 3}$ & 5 & - & - & 0.021 & 9 \\
\hline Daisy Fleabane & Native & - & - & 0.032 & 6 & - & - & - & - \\
\hline Yellow Foxtail & Invasive & - & - & 0.029 & 7 & - & - & 0.221 & 2 \\
\hline Giant Foxtail & Invasive & 0.001 & 17 & 0.014 & 8 & - & - & - & - \\
\hline Partridge Pea & Native & - & - & 0.004 & 10 & - & - & - & - \\
\hline Chinese Bushclover & Invasive & - & - & - & - & 0.423 & $\mathbf{1}$ & - & - \\
\hline Wild Blackberry & Native & - & - & - & - & 0.185 & 3 & - & - \\
\hline Tall Fescue & Invasive & - & - & - & - & $\mathbf{0 . 0 3 3}$ & 4 & - & - \\
\hline Yellow Indiangrass & Native & 0.001 & 12 & - & - & 0.027 & 5 & - & - \\
\hline Wingstem & Native & - & - & - & - & 0.009 & 9 & - & - \\
\hline Ashy Sunflower & Native & - & - & - & - & - & - & 0.449 & 1 \\
\hline Flowering Spurge & Native & - & - & - & - & - & - & 0.059 & 3 \\
\hline Rough Buttonweed & Native & - & - & - & - & - & - & 0.041 & 5 \\
\hline Prickly Sow Thistle & Invasive & - & - & - & - & - & - & 0.034 & 6 \\
\hline Beaked Panicgrass & Native & - & - & - & - & - & - & 0.033 & 7 \\
\hline Prairie Cordgrass & Native & - & - & - & - & - & - & 0.026 & 8 \\
\hline Dogbane & Forb & - & - & - & - & - & - & 0.014 & 10 \\
\hline
\end{tabular}

Table 3. Top 10 plant species proportions by study site. 


\begin{tabular}{|l|c|l|l|l|}
\hline & JMF & \multicolumn{1}{|c|}{ Landfill } & \multicolumn{1}{c|}{ Bernheim } & \multicolumn{1}{c|}{ Iroqouis } \\
\hline Plant Species & $\begin{array}{l}\text {-Rattlesnake Master } \\
\text {-Virginia Wild Rye }\end{array}$ & $\begin{array}{l}\text {-Big Bluestem } \\
\text {-Partridge Pea } \\
\text {-Switchgrass } \\
\text {-Prairie Dock }\end{array}$ & $\begin{array}{l}\text { No information } \\
\text { available for } \\
\text { original plantings }\end{array}$ & $\begin{array}{l}\text {-Big Bluestem } \\
\text {-Little Bluestem } \\
\text {-Prairie Cordgrass } \\
\text {-Rattlesnake Master } \\
\text {-Downy Sunflower }\end{array}$ \\
\hline $\begin{array}{l}\text { Total Species } \\
\text { Seeded }\end{array}$ & 18 & 19 & N/A & 45 \\
\hline
\end{tabular}

Table 4. Plant species retained from original seeding.

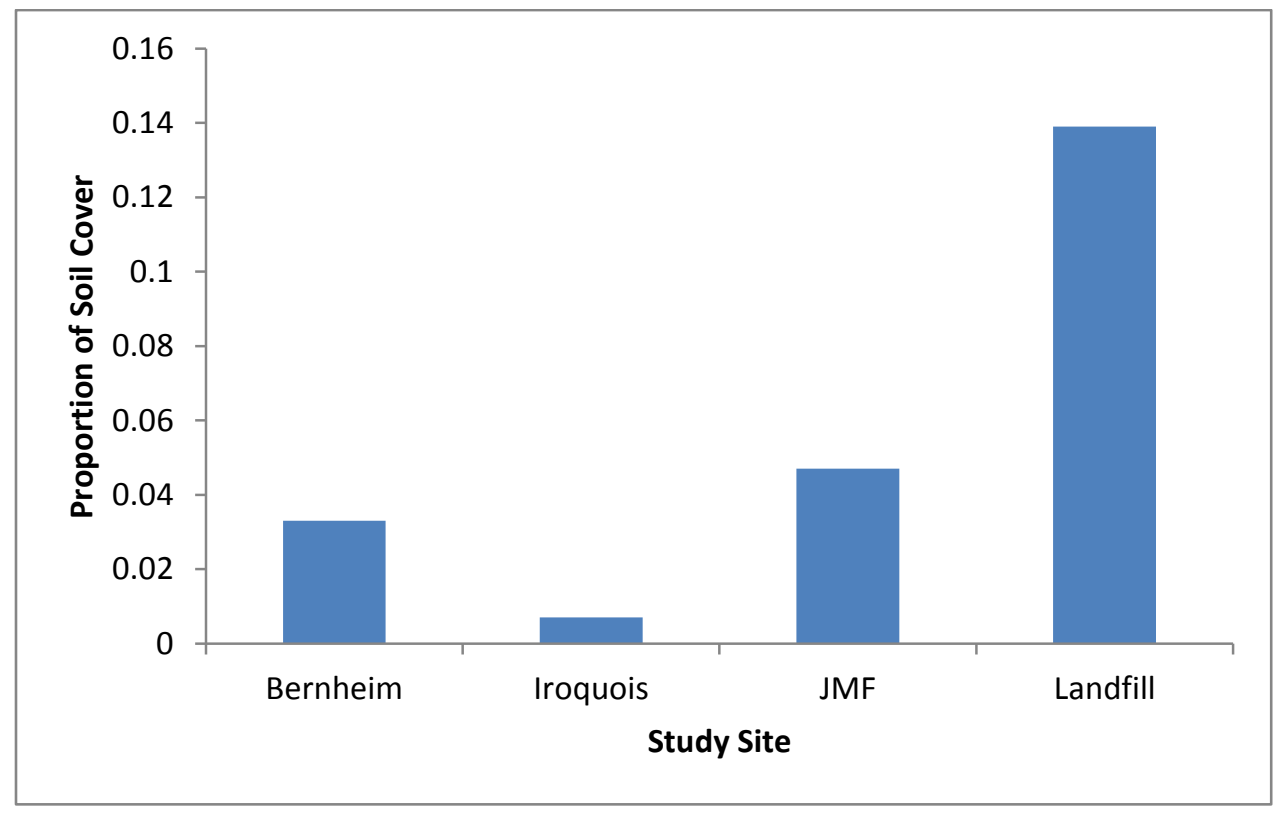

Fig. 4. Proportion of soil cover by site. The Landfill had the highest proportion of soil cover and Iroquois had the lowest. 


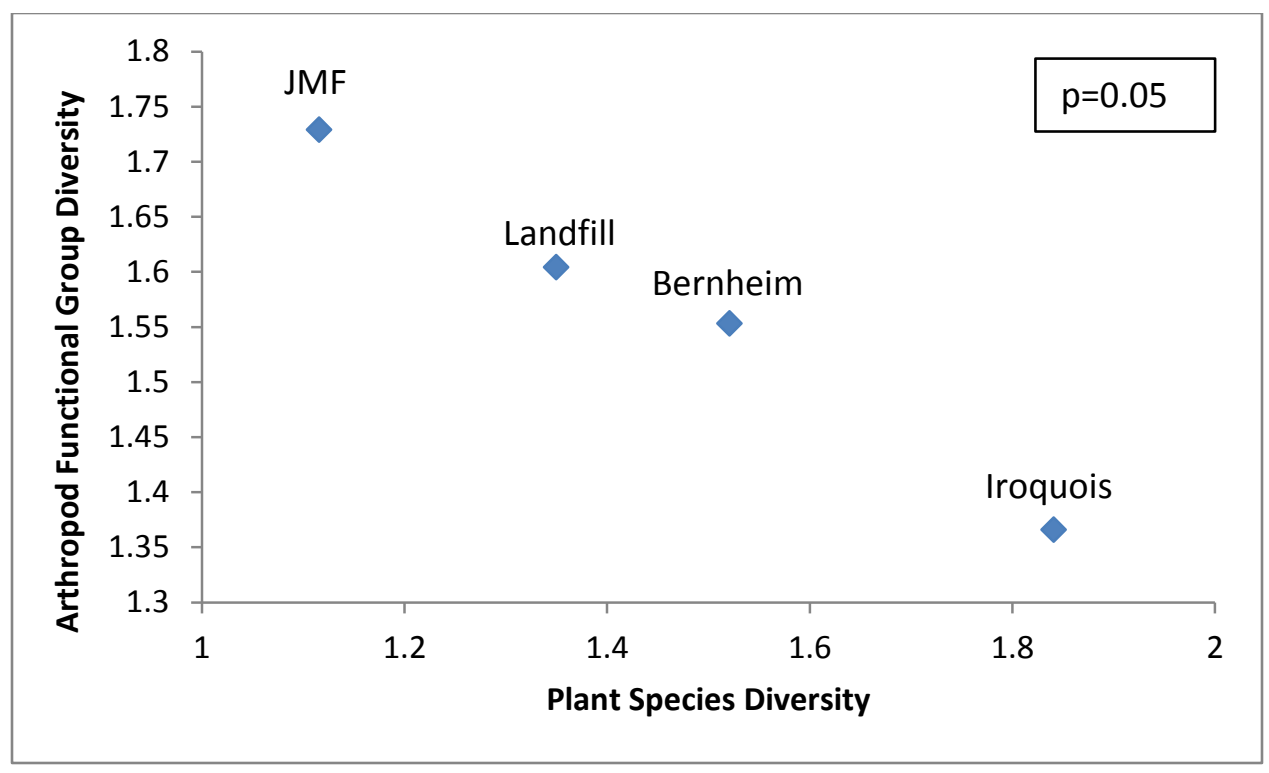

Fig. 5. Plant species diversity and arthropod functional group diversity. There was a significant negative relationship between the two.

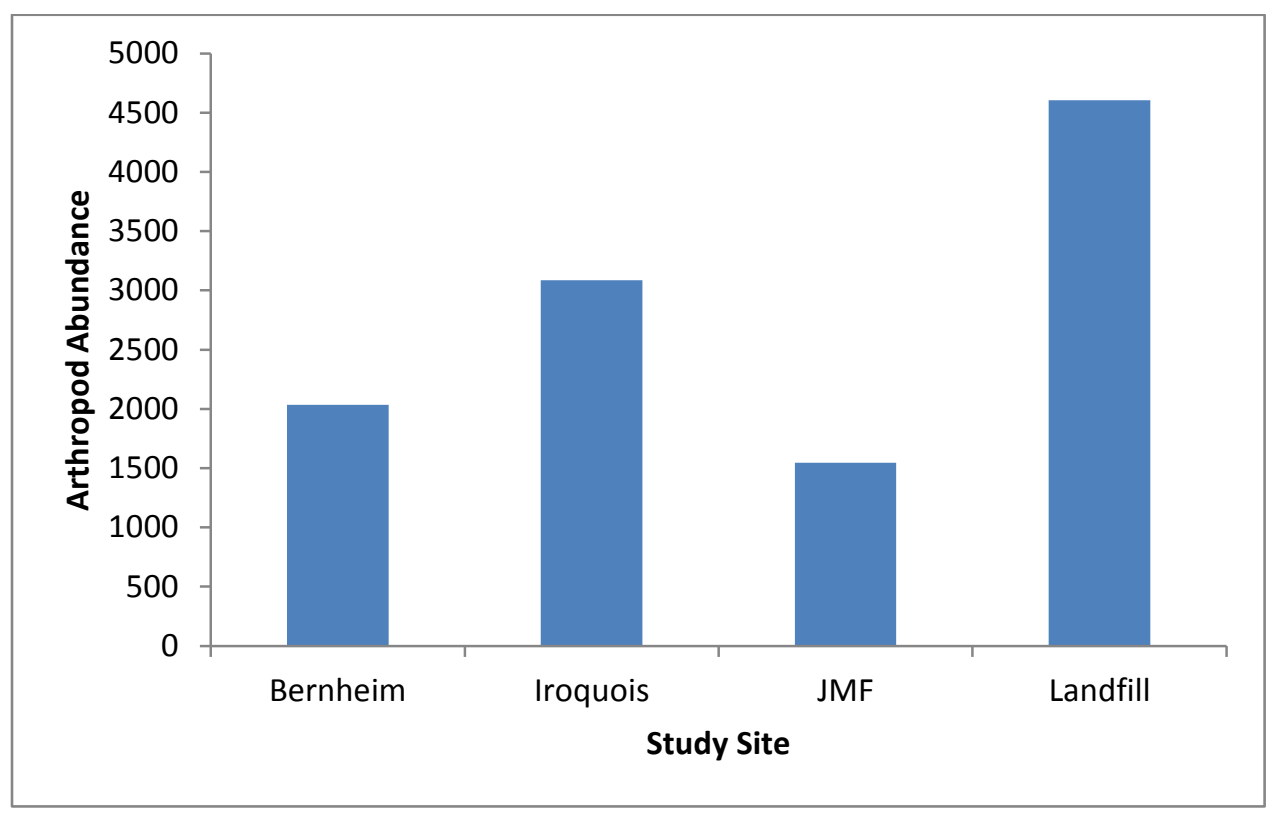

Fig. 6. Arthropod abundance by site. The Landfill had the highest arthropod abundance of all the sites by a considerable margin. 


\begin{tabular}{|c|c|c|c|c|c|c|c|c|c|c|c|c|}
\hline \multirow[b]{2}{*}{ Group } & \multicolumn{3}{|c|}{$\mathrm{JMF}$} & \multicolumn{3}{|c|}{ Landfill } & \multicolumn{3}{|c|}{ Bernheim } & \multicolumn{3}{|c|}{ Iroquois } \\
\hline & Rank & Abundance & $\begin{array}{l}\% \text { of } \\
\text { Total }\end{array}$ & Rank & Abundance & $\begin{array}{l}\% \text { of } \\
\text { Total }\end{array}$ & Rank & Abundance & $\begin{array}{l}\% \text { of } \\
\text { Total }\end{array}$ & Rank & Abundance & $\begin{array}{l}\% \text { of } \\
\text { Total }\end{array}$ \\
\hline Cicadellidae & 1 & 221 & 14.3 & 3 & 363 & 7.9 & 2 & 402 & 19.8 & 3 & 336 & 10.9 \\
\hline Microdiptera & 2 & 221 & 14.3 & 2 & 503 & 10.9 & 3 & 261 & 12.8 & 4 & 259 & 8.4 \\
\hline Isopoda & 3 & 174 & 11.3 & 1 & 1675 & 36.4 & 5 & 74 & 3.6 & 11 & 50 & 1.6 \\
\hline Formicidae & 4 & 164 & 10.6 & 14 & 53 & 1.2 & 1 & 471 & 23.2 & 1 & 1107 & 35.9 \\
\hline Diptera & 5 & 141 & 9.1 & 4 & 306 & 6.6 & 4 & 124 & 6.1 & 2 & 360 & 11.7 \\
\hline Lycosidae & 6 & 106 & 6.9 & 8 & 142 & 3.1 & 7 & 60 & 3.0 & 7 & 96 & 3.1 \\
\hline Miridae & 7 & 54 & 3.5 & 5 & 284 & 6.2 & 8 & 54 & 2.7 & 13 & 37 & 1.2 \\
\hline Acrididae & 8 & 38 & 2.5 & 6 & 246 & 5.3 & 9 & 47 & 2.3 & 5 & 118 & 3.8 \\
\hline Chrysomelidae & 9 & 34 & 2.2 & 27 & 15 & 0.3 & 14 & 29 & 1.4 & 9 & 70 & 2.3 \\
\hline Curculionidae & 10 & 34 & 2.2 & 12 & 64 & 1.4 & - & - & - & 20 & 18 & 0.6 \\
\hline Ixodidae & 11 & 34 & 2.2 & - & - & - & - & - & - & 39 & 3 & 0.1 \\
\hline Salticidae & 16 & 18 & 1.2 & 20 & 21 & 0.5 & 6 & 65 & 3.2 & 10 & 51 & 1.7 \\
\hline Aphididae & 21 & 11 & 0.7 & 7 & 200 & 4.3 & 26 & 9 & 0.4 & 35 & 4 & 0.1 \\
\hline Halictidae & 22 & 9 & 0.6 & 22 & 19 & 0.4 & 11 & 34 & 1.7 & - & - & - \\
\hline Gryllidae & 24 & 8 & 0.5 & 10 & 70 & 1.5 & 15 & 23 & 1.1 & 19 & 20 & 0.6 \\
\hline Collembola & 26 & 7 & 0.5 & 29 & 15 & 0.3 & 12 & 33 & 1.6 & 8 & 80 & 2.6 \\
\hline Delphacidae & 43 & 2 & 0.1 & 50 & 1 & 0.0 & 10 & 45 & 2.2 & 12 & 46 & 1.5 \\
\hline Oxyopidae & - & - & - & 9 & 134 & 2.9 & 13 & 33 & 1.6 & 32 & 6 & 0.2 \\
\hline Tingidae & - & - & - & - & - & - & 46 & 2 & 0.1 & 6 & 113 & 3.7 \\
\hline
\end{tabular}

Table 5. Top 10 arthropod group abundances by study site. 


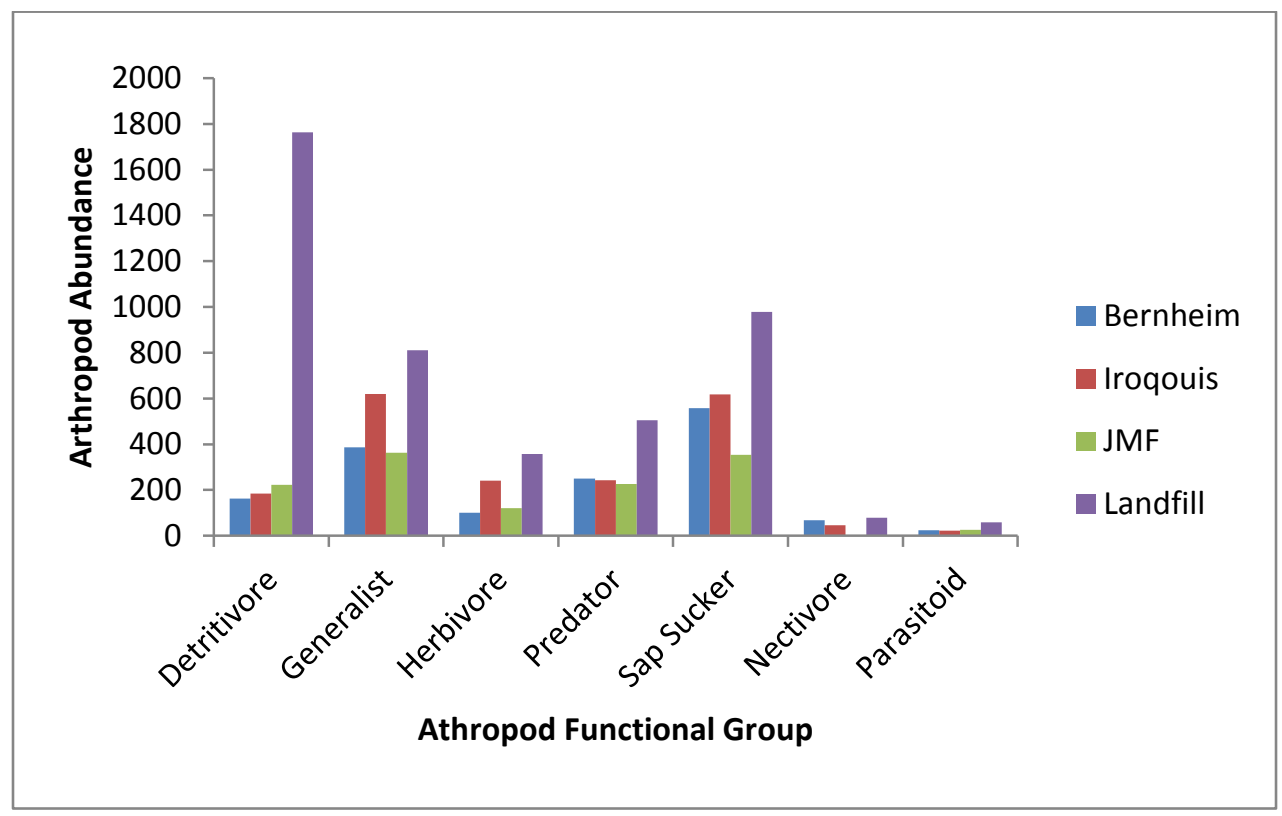

Fig. 7. Arthropod abundance by functional group, Part 1. The Landfill has the highest abundance of arthropods in all functional groups.

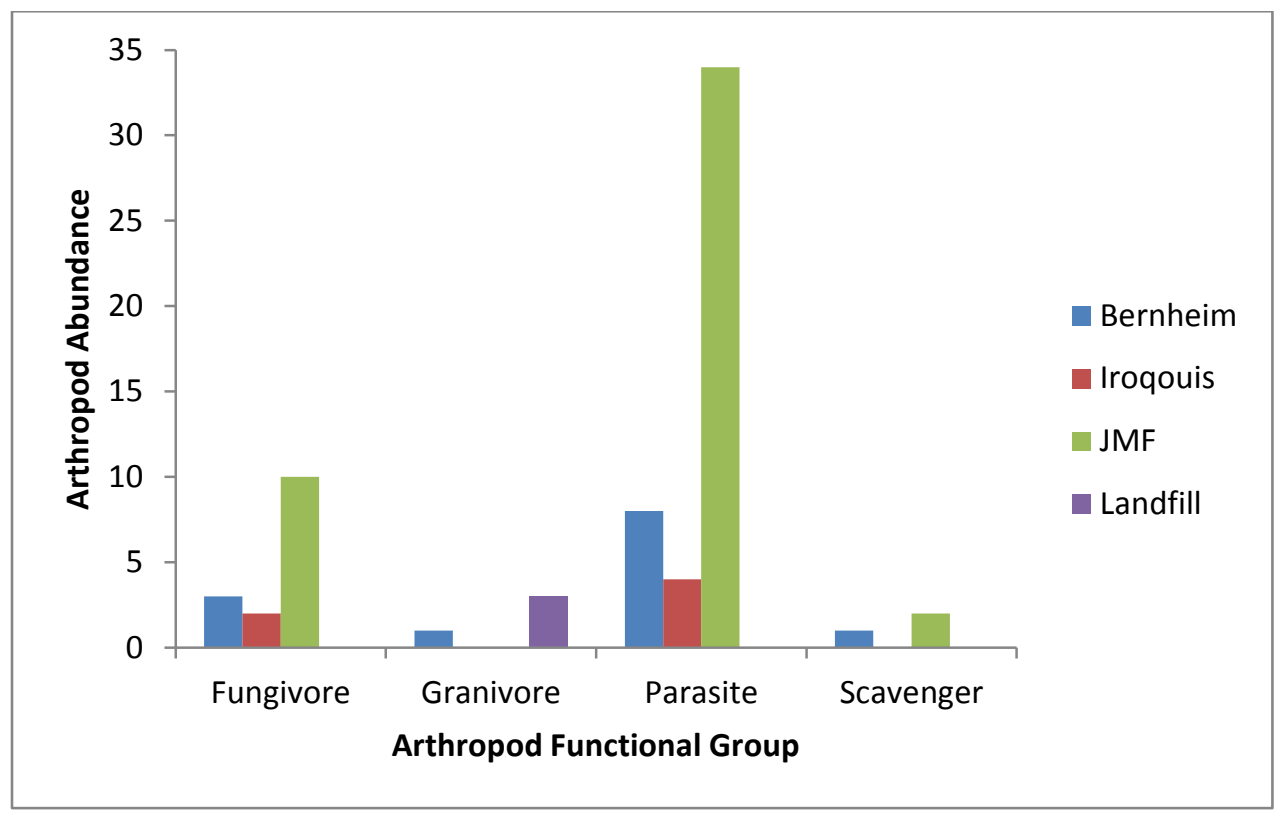

Fig. 8. Arthropod abundance by functional group, Part 2. Parasite abundance was highest at JMF and granivores and scavengers were only found at two sites. 


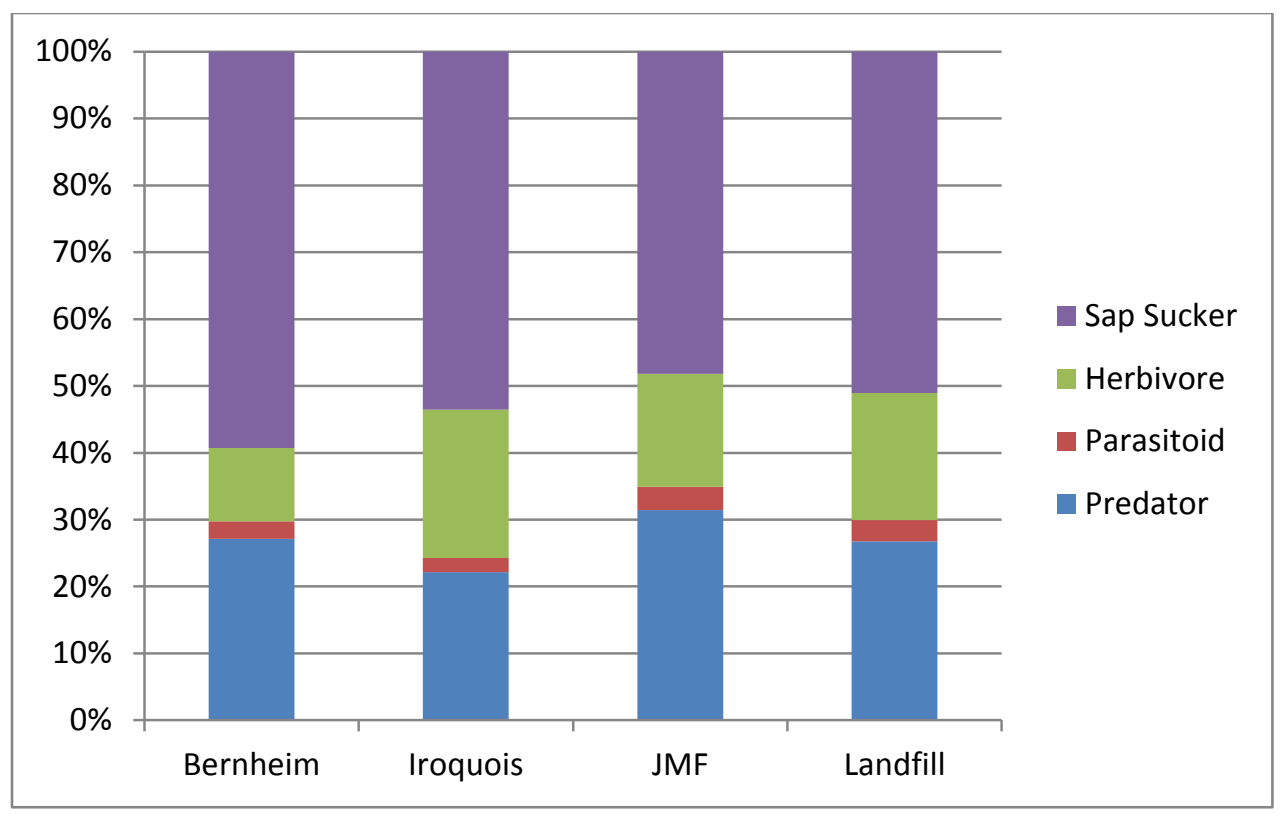

Fig. 9. Proportion of predators, sap suckers, herbivores, and parasitoids by site. The proportions of each functional group are very similar across sites.

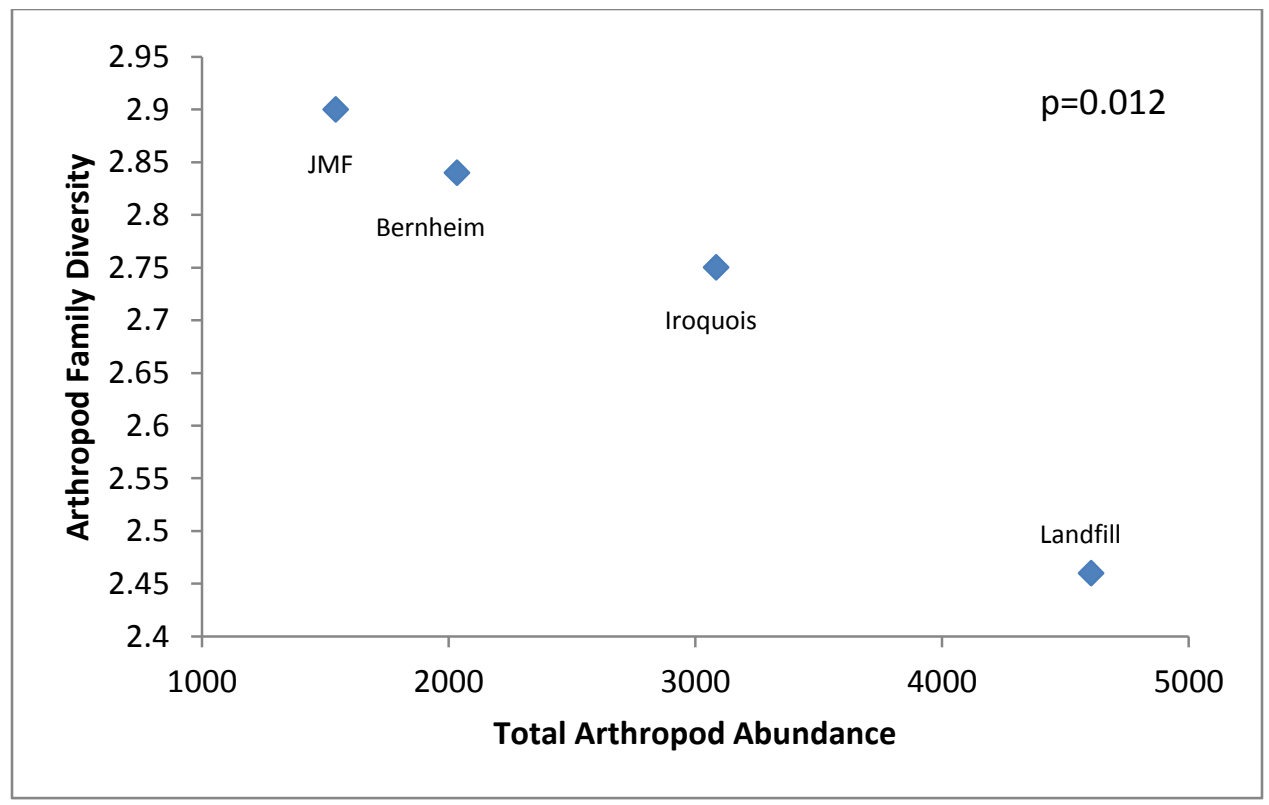

Fig. 10. Arthropod family diversity decreases as total arthropod abundance increases due to dominance of particular families of arthropods. 


\begin{tabular}{|l|c|c|c|c|}
\hline & JMF & Landfill & Bernheim & Iroquois \\
\hline $\begin{array}{l}\text { Arthropod Family } \\
\text { Richness }\end{array}$ & 57 & 55 & 63 & 64 \\
\hline $\begin{array}{l}\text { Arthropod Family } \\
\text { Diversity }\end{array}$ & 2.928 & 2.494 & 2.747 & 2.505 \\
\hline $\begin{array}{l}\text { Arthropod Family } \\
\text { Evenness }\end{array}$ & 0.724 & 0.622 & 0.663 & 0.602 \\
\hline $\begin{array}{l}\text { Arthropod Functional } \\
\text { Group Diversity }\end{array}$ & 1.729 & 1.604 & 1.553 & 1.366 \\
\hline $\begin{array}{l}\text { Arthropod Functional } \\
\text { Group Evenness }\end{array}$ & 0.236 & 0.190 & 0.204 & 0.170 \\
\hline
\end{tabular}

Table 6. Arthropod richness, diversity, and evenness result. 


\section{DISCUSSION}

Plant diversity at each site also varied substantially as can be seen in Table 2 . Interestingly, there was less overlap in species presence across sites than one might expect in the top 10 species of each site. Species like Johnson grass and common ragweed were found across three of the four sites but were absent in Iroquois. This is probably because none of these were planted at the site and there is probably little chance of colonization from surrounding areas due to Iroquois's urban situation. Iroquois contained the highest species richness and diversity, possibly because it is the oldest, although second-most urban site. Due to similar maintenance techniques at Iroquois, Bernheim, and JMF, this could indicate that site age could impact prairie ecosystem complexity. This result is similar to what Kindscher and Tieszen 1998 found, with increased diversity as the site ages. However, this result is contrary to what Sluis 2002 found, which found that as the restoration age increased, plant diversity decreased. This highlights the fact that little is currently known about the effect of age on diversity in prairies.

The Landfill and Bernheim were the only sites to contain legumes, and legumes were dominant at Bernheim. This exotic legume most likely got a strong foothold at Bernheim because legumes fix nitrogen in the soil. Given the high dominance of this invasive legume, it is surprising that Bernheim supports the highest functional group diversity. This could be due to a trade-off between its suppressing other species because

of its dominance and the benefits of its nitrogen fixing, which provides more nutrients for 
other functional groups. Bernheim had a much higher proportion of cool season grasses than did the other sites, and the Landfill had a very low proportion of that functional group. Iroquois and JMF were the only sites to contain sedges and rushes, and while this functional group does not have a particularly large impact on the ecosystem functioning of the prairies, their presence speaks to the diversity of these sites (Sivicek and Taft 2011). At JMF and the Landfill, warm season grasses were dominant due to the high incidence of Johnson grass as discussed earlier. Forbs were dominant at Iroquois, and the proportion of warm season grasses was lowest at Bernheim.

The number of species retained from original plantings was surprisingly low, highlighting the difficulty of ensuring all the plants seeded actually flourish. Iroquois retained the highest number of species at five, compared to the 45 species originally seeded, this value is extremely low. Both JMF and Iroquois retained $11.1 \%$ species seeded, with JMF retaining two species form the original 18 . The Landfill demonstrates that species can disappear rapidly, as at that site only four of 19 seeded species remained after only two years. No information could be collected about seeding from Bernheim. These low numbers of retention highlight the difficulties of seeding restored sites and reflect the colonization of both native and non-native species of these restorations, as there were more than just the retained species found at each site. It should be noted that some of the planted species may remain elsewhere in the site, just not in the collection grids.

Surprisingly, although JMF had the highest plant biomass, and therefore the highest productivity, it supported the lowest arthropod abundance. This contrasts with several previous studies which have shown a strong positive relationship between plant 
biomass and arthropod abundance (Haddad et al. 2001). The dominance of the invasive Johnson grass could explain this anomaly, as exotic plants tend to exhibit greater aboveground biomass (Wilsey et al. 2009). Johnson grass has very high productivity but is not as palatable as forbs or other native grasses so it would not be expected to support high diversity of arthropods (Rout et al. 2013). At JMF, Johnson grass constituted 57\% of the total plant cover. To further highlight its high productivity, the second highest plant biomass site was the Landfill which was also highly dominated by Johnson grass, which constituted 52\% of plant cover at the Landfill. The productivity at these two sites might have been expected to be similar, given the relatively similar proportions of cover by Johnson grass. The greater productivity at JMF was likely due to the greater height of Johnson grass there.

Iroquois was the only site that did not host Johnson grass, and even with the absence of this sometimes large contributor to biomass, Iroquois still had a higher biomass than Bernheim by over 100g. This may have been because Iroquois had the highest plant species diversity of all the sites, given that high biodiversity often supports higher productivity (Tilman et al. 2001, Fornara and Tilman 2009, Tilman et al. 2012, Reich et al. 2012, Hector et al. 1999), although in this study, Johnson grass was the highest producer.

Despite the low abundance of arthropods at JMF, the site contained the highest arthropod functional group diversity. The negative relationship between plant species diversity and arthropod functional group diversity seen in Fig. 5 is surprising. As highlighted by Panzer and Schwartz (1998), higher plant species diversity would be expected to support higher arthropod diversity. I believe the confounding factor of my 
results is the dominance of certain arthropod groups, which decreased the diversity measures.

Study site surroundings could also have an effect on the relationship between arthropods and plants although the effects of such factors cannot be statistically analyzed due to the low sample size of the study. Bernheim is the largest, most rural prairie of the four study sites, increasing the likelihood that despite dominance by an invasive, the arthropods could be supplied by surrounding areas, increasing its family diversity (Bomar 2001, Pöyry et al. 2009). Conversely, JMF has a three meter mowed section between the prairie and the surrounding woods. This could reduce arthropod colonization from the surroundings, a reduction compounded by the dominance of the exotic Johnson grass. With few nearby sources of arthropods and little time for colonization, the Landfill which was the youngest, and most urban prairie, had the lowest arthropod family richness as well as plant species richness (Déri et al. 2011).

Arthropod abundance per site varied considerably. The Landfill had the highest arthropod abundance, with well over four thousand arthropods while JMF had the lowest abundance with around fifteen hundred. The substantially higher abundance at the Landfill can be explained by the disproportionately high abundances of isopods, microdipterans, and sap suckers, aphids in particular, which were not found in large abundances in the other sites. Isopods were particularly abundant at the Landfill, where they constituted over a third of the abundance. This may be due to its being the most disturbed of the four sites. A study by Magrini et al. 2011 found that isopod abundance was considerably higher in the more urban and disturbed areas. Additionally, due to the 
herbicide spread in the Landfill midway through the season, there was considerably more detritus at the Landfill than the other sites, increasing resources for isopods.

Examination of arthropod abundance by functional group shows that the Landfill had consistently higher abundance in all functional groups save scavengers, fungivores, and parasites, which were lacking from the Landfill. The extremely low abundances of these groups as well as granivores and nectivores in all sites could be simply from sampling error. However, the absence of parasites is most likely due to the isolation of the Landfill by both its urban situation as well as a high chain-link fence, both of which would tend to reduce populations of the larger mammals on which the parasites might feed. Conversely, the larger abundance of parasites at JMF compared to the other sites might be due its suburban location. These surroundings may have resulted in high numbers of large mammals due to the importance of early successional habitat which is limited and isolated in suburban areas because of roads and other barriers (Litvaitis 2001). Although scavengers were found only at Bernheim and JMF, due to the low incidence of these groups, it is most likely a product of chance that they were found there, perhaps because carrion happened to be located near the traps at those sites.

Comparing prey and host species to predators and parasitoids, revealed that the proportions of each group were similar across the study sites. Sap suckers and herbivores were chosen as the main prey groups because they include the most abundant prey species found in prairie food chains (Nemec and Bragg 2008, Wallner et al. 2013, Rowe and Holland 2013). Bernheim supported the highest proportion of sap suckers and the lowest proportion of herbivores, possibly due to a high dominance of legumes. Iroquois was found to have the highest proportion of sap suckers and herbivores and the lowest 
proportion of predators. This slight difference in predator/prey proportions at Iroquois compared to the other study sites supports the notion that increasing habitat complexity caused by higher plant diversity makes it more difficult for predators to find prey, decreasing their success (Hunter and Price 1992).

Surprisingly, as total arthropod abundance increased, arthropod family diversity decreased significantly. This pattern is contrary to the more usual pattern, which is a positive correlation between abundance and diversity. The result in this study may be explained by the extreme dominance of the particular family groups such as isopods at the Landfill and formicids at Iroquois park, both of which constituted over a third of the total abundance at their respective sites. Further research should be done in urban settings to discover whether the pattern I observed is typical in those habitats.

In a restoration, either high plant species or functional group diversity is the most favorable outcome and goal of these restoration projects. High plant diversity supports high arthropod family richness through increased availability of food and protection from predators. I believe that the confounding results of decreased arthropod functional group diversity as plant species diversity increased was due to disproportionate abundances of arthropod groups. Because the study was not well replicated, no definitive information could be gleaned concerning the effect of site age, surroundings, or management techniques. The implication for management is that more effort should be put into seeding high plant species diversity plots which are more stable and can better resist invasion. 
There were many factors affecting the precision of arthropod data collection at each site. Bernheim and JMF were plagued by trap predation, most likely from nocturnal mammals during the nights in which the pitfall traps were open. Covering the traps helped to deter some predation; however, at JMF in particular, there were two weeks in which almost a quarter of the traps were predated on and all data were lost.

Additional difficulties at JMF resulted from the height and density of vegetation due to the Johnson grass. This caused some complications during sweep-netting because of the difficulty of moving through the vegetation at a metered pace and the hindrance of performing a full sweep to either side. These challenges could have caused insect abundance and diversity to not be fully measured at JMF. Johnson grass did not cause as many problems in sweeping at the Landfill because it did not reach the height that it did at JMF. There were other difficulties encountered at the Landfill, resulting from the fact that the plots used are still actively undergoing restoration procedures. Due to uncontrollable weather conditions, Imazapic ${ }^{\circledR}$ herbicide treatment at the Landfill was pushed to the end of May, causing a massive vegetative die-off in the middle of data collection. This is most likely the reason for such high detritivore abundance at the Landfill compared to the other study sites. Additionally, when driving through the plots used for the study in order to reach other plots, the mowers often drove directly though the transects used in this study, tamping down vegetation and disrupting the transect. Again, this most likely could have reduced abundance or diversity of the site by compromising the collection methods. This is interesting because despite site disruption, the Landfill still had extremely high arthropod abundance. Lastly, among those site whose management technique is burning, Iroquois was the most recent site to be burned. 
Iroquois was burned the spring before collection, i.e. in spring 2012, Bernheim was most recently burned in spring 2009, and JMF was most recently burned spring in 2010. This may have had an effect on arthropods found in Iroquois. Reed (1997) reported that the year following a burning, forbs and grasses develop and flower earlier in the season compared to sites which were not burned the previous season. This early emergence would attract arthropods back to the site quickly, reestablishing their abundance and thus Iroquois's arthropod abundances may have been relatively high because of the close proximity in time of its burn and my study.

Despite challenges during actual collection, there are other reasons that my results look different from other studies completed. As discussed earlier, I did not have the replication that other studies had, which would assist in being able to report robust correlations. Similarly, with only 4 sites, it is hard to get statistically significant data that has a strong relationship to make thorough comparisons. Because of the various attribute differences of each site, I could not compare each site directly. I decided to compare plant diversity to arthropod diversity because there would be relationships across sites with similar plants and arthropods. Unfortunately, there are many factors that affect arthropod abundance in a site other than just plants, such as proximity to urban surroundings (Williams et al. 2005). I collected plant data at the end of July, which would affect the plant species that were flowering and more abundant at that time. Consequently, there were more warm season grasses than were abundant during the earlier part of the summer. Another factor that affected my results was the lack of a remnant prairie to make comparisons with. Most of the previous studies compared plants to arthropods using 
remnant and restored prairies, which traditionally offer drastic comparisons and relationships. 


\section{REFERENCES}

Bomar, C. R. 2001. Comparison of grasshopper (Orthoptera: Acrididae) communities on remnant and reconstructed prairies in western Wisconsin. Journal of Orthoptera Research 10: 105-112.

Brand, R.H. and Dunn, C.P. 1998. Diversity and Abundance of Springtails (Insecta: Collembola) in Native and Restored Tallgrass Prairies. American Midland Naturalist 139: 235-242.

Daubenmire, R. 1959. A canopy coverage method of vegetation analysis. Northwest Science 33:43-64.

Dennis, P., Young, M.R., and Gordon, I.J. Distribution and abundance of small insects and arachnids in relation to structural heterogeneity of grazed, indigenous grasslands. Ecological Entomology 23: 253-264.

Déri, E., Magura, T., Horváth, R., Máté, K., Ruff, G., Lengyel, S., and Tóthmérész, B. 2011. Measuring the Short-term Success of Grassland Restoration: The Use of Habitat Affinity Indicies in Ecological Restoration. Restoration Ecology 19: 520528.

Frankie, G.W. and Ehler, L.E. 1978. ECOLOGY OF INSECTS IN URBAN ENVIRONMENTS. Annual Review of Entomology 23: 367-87.

Fornara, D.A. and Tilman, D. 2009. Ecological Mechanisms Associated with the Positive Diversity: Productivity Relationship in a N-Limited Grassland. Ecology 90: 408418.

Gusmeroli, F., Marianna, D., Fava, F. et al. 2013. Effects of ecological, landscape and management factors on plant species composition, biodiversity and forage value in Alpine meadows. Grass and Forage Science 68: 437-447.

Haddad, N.M., Tilman, D., Haarstad, J., Ritchie, M., and Knops, J.M.H. 2001.

Contrasting Effects of Plant Richness and Composition on Insect Communities: A Field Experiment. American Naturalist 158: 17-35.

Hartley, D.J., Koivula, M.J., Spence, J.R., Pelletier, R., and Ball, G.E. 2007. Effects of urbanization on ground beetle assemblages (Coleoptera, Carabidae) of grassland habitats in western Canada. Ecography 30: 673-684.

Hector, A., Schmid, B., Beierkuhnlein, C., Caldeira, M.C., Diemer, M., Dimitrakopoulos, P.G., Finn, J.A., Freitas, H., Giller, P.S., Good, J., Harris, R., Högberg, P., HussDanell, K., Joshi, J., Jumpponen, A., Körner, C., Leadley, P.W., Loreau, M., Minns, A., Mulder, C.P.H., O’Donovan, G., Otway, S.J., Pereira, J.S., Prinz, A., 
Read, D.J., Scherer-Lorenzen, M., Schulze, E.D., Siamantziouras, A.S.D, Spehn, E.M., Terry, A.C., Troumbis, A.Y., Woodward, F.I., Yachi, S., and Lawton, J.H. 1999. Science 286: 1123-1126.

Howe, H.F. 1994. Species Diversity in Tallgrass Prairie: Assumptions and Implications. Conservation Biology 8: 691-704.

Hunter, M. D. and Price, P.W. 1992. Playing Chutes and Ladders: Heterogeneity and the Relative Roles of Bottom-Up and Top-Down Forces in Natural Communities. Ecology 73(3): 724-732.

IBM Corp. Released 2012. IBM SPSS Statistics for Windows, Version 21.0. Armonk, NY: IBM Corp

Joern, A. 1982. Vegetation Structure and Microhabitat Selection in Grasshoppers (Orthoptera, Acrididae). Southwestern Naturalist 27: 197-209.

Jonas, J.L., Whiles, M.R., and Charlton, R.E. 2002. Aboveground Invertebrate Responses to Lnad Management Differences in a Central Kansas Grassland. Community and Ecosystem Ecology 31: 1142-1152.

Kateb, H.E., Zhang, H., Zhang, P., and Mosandi, R. 2013. Soil erosion and surface runoff on different vegetation covers and slope gradients: A field experiment in Southern Shaanxi Province, China. Catena 105: 1-10.

Kershaw, M.H. and Mallik, A.U. 2013. Predicting Plant Response to Disturbance: Applicability of the Intermediate Disturbance Hypothesis and Mass Ratio Hypothesis. Critical Reviews in Plant Sciences 32: 383-395.

Koper, N., Mozel, K. E., and Henderson, D.C. 2010. Recent declines in northern tallgrass prairies and effects of patch structure on community persistence. Biological Conservation 143: 220-229.

Larson D.L. and Larson, J.L. 2010. Control of one invasive plant species allows exotic grasses to become dominant in northern Great Plains grasslands. Biological Conservation 143: 1901-1910.

Litvaitis, J.A. 2001. Importance of early successional habitats to mammals in eastern forests. Wildlife Society Bulletin 29: 466-473.

Looney, C., Caldwell, B.T., Eigenbbrode, S.D. 2009. When the prairie varies the importance of site characteristics for strategising insect conservation. Insect Conservation and Diversity 2: 243-250.

Magrini, M.J., Freitas, A.V.L., Uehara-Prado, M. 2011. The effects of four types of anthropogenic disturbances on composition and abundance of terrestrial isopods (Isopoda: Oniscidea). Zoologia 28: 63-71.

Marshall, S.A. (2006) Insects- Their Natural History and Diversity: with a photographic guide to insects of eastern North America. Buffalo, NY: Firefly. 
Martin, L.M., Moloney, K.A., Wilsey, B.J. 2005. An assessment of grassland restoration success using species diversity components. Journal of Applied Ecology 42: 327336.

McKinney, M.L. and Lockwood, J.L. 1999. Biotic homogenization: a few winners replacing many losers in the next mass extinction. Tree 14: 450-453.

Morris, M.G. 2000. The effects of structure and its dynamics on the ecology and conservation of arthropods in British grasslands. Biological Conservation 95: 129142.

Murdoch, W.W., Evans, F.C., and Peterson, C.H. 1972. Diversity and Pattern in Plants and Insects. Ecology 53: 819-829.

Nemec, K.T. and Bragg, T.B. 2008. Plant-Feeding Hemiptera and Orthroptera Communities in Native and Restored Mesic Tallgrass Prairies. Restoration Ecology 16: 324-335.

Öckinger, E. and Smith, H.G. 2007. Semi-natural grasslands as population sources for pollinating insects in agricultural landscapes. Journal of Applied Ecology 44: 5059.

Panzer, R. 2002. Compatibility of Prescribed Burning with the Conservation of Insects in Small, Isolated Prairie Reserves. Conservation Biology 16:1296-1307.

Panzer, R. and Schwartz, M.W. 1998. Effectiveness of a Vegetation-Based Approach to Insect Conservation. Conservation Biology 12: 693-702.

Pokorny, M.L., Sheley, R.L., Zabinski, C.A., Engel, R.E., Svejcar, T.J., and Borkowski, J.J. 2005. Plant Functional Group Diversity as a Mechanism for Invasion Resistance. Restoration Ecology 13: 448-459.

Porter, J. 2012. Lessons from the Dust Bowl: Human-Environment Education on the Great Plains. Journal of Geography 111: 127-136.

Pöyry, J., Paukkunen, J., Heliölä, J., and Kuussaari, M. 2009. Relative contributions of local and regional factors to species richness and total density of butterflies and moths in semi-natural grasslands. Oecologia 160: 577-587.

Reed, C.C. 1997. Responses of Prairie Insects and Other Arthropods to Prescription Burns. Natural Areas Journal 17: 380-385.

Reich, P.B., Tilman, D., Isbell, F., Mueller, K., Hobbie, S.E., Flynn, D.F.B., and Eisenhauer, N. 2012. Impacts of Biodiversity Loss Escalate Through Time as Redundancy Fades. Science 336: 589-592.

Rout, M.E., Chrzanowski, T.H., Smith, W.K., and Gough, L. 2013. Ecological impacts of the invasive grass Sorghum halepense on native tallgrass prairie. Biological Invasions 15: 327-339. 
Rowe, H.I. 2010. Tricks of the Trade: Techniques and Opinions from 38 Experts in Tallgrass Prairie Restoration. Restoration Ecology 18: 253-262.

Rowe, H.I. and Holland, J.D. 2013. High Plant Richness in Prairie Reconstructions Support Diverse Leafhopper Communities. Restoration Ecology 21: 174-180.

Siemann, E., Tilman, D., Haarstad, J., and Ritchie, M. 1998. Experimental Tests of the Dependence of Arthropod Diversity on Plant Diversity. American Naturalist 152: 738-750.

Siemann, E. 1998. Experimental Tests on Effects of Plant Productivity and Diversity on Grassland Arthropod Diversity. Ecology 79: 2057-2070.

Silletti, A.M., Knapp, A.K., and Blair, J.M. 2004. Competition and coexistence in grassland codominants: responses to neighbor removal and resource availability. Canadian Journal of Botany 82: 450-460.

Sivicek, V.A. and Taft, J.B. 2011. Functional Group Density as an index for assessing habitat quality in tallgrass prairie. Ecological Indicators 11: 1251-1258.

Sluis, W.J. 2002. Patterns of Species Richness and Composition in Re-Created Grassland. Restoration Ecology 10: 677-684.

Souty-Grosset, C., Badenhausser, I., Reynolds, J.D., and Morel, A. 2005. Investigations on the potential of woodlice as bioindicators of grassland habitat quality. European Journal of Soil Biology 41: 109-116.

Summerville, K.S., Bonte, A.C., and Fox, L.C. 2007. Short-Term Temporal Effects on Community Structure of Lepidoptera in Restored and Remnant Tallgrass Prairies. Restoration Ecology 15: 179-188.

Summerville, K.S. 2008. Species diversity and persistence in restored and remnant tallgrass prairies of North America: a function of species' life history, habitat type, or sampling bias? Journal of Animal Ecology 77: 487-494.

Symstad, A.J. 2002. An overview of ecological plant classification systems: linking functional response and functional effect groups. Modern Trends in Applied Terrestrial Ecology

Tilman, D. and Downing, J.A. 1994. Biodiversity and stability in grasslands. Nature 367: 363-365.

Tilman, D. 1997. Community Invasibility, Recruitment Limitation, and Grassland Biodiversity. Ecology 78: 81-92.

Tilman, D., Knops, J., Wedin, D., Reich, P., Ritchie, M., and Siemann, E. 1997. The Influence of Functional Diversity and Composition on Ecosystem Processes. Science 277: 1300-1302. 
Tilman, D., Reich, P.B., and Isbell, F. 2012. Biodiversity impacts ecosystem productivity as much as resources, disturbance, or herbivory. Preceedings of the National Academy of Sciences 109: 10394-10397.

Ubick, D., Paquin, P., Cushing, P.E., and Roth, V. (eds). (2005) Spiders of North America: an identification manual. Keene, NH: American Arachnological Society.

Wallner, A.M., Molano-Flores, B., and Dietrich, C.H. 2013. Using Auchenorrhyncha (Insecta: Hemiptera) to develop a new insect index in measuring North American tallgrass prairie quality. Ecological Indicators 25: 58-64.

Wilkinson, D.M. 1999. The Disturbing History of Disturbance. Oikos 84: 145-147.

Williams, N.S.G., Morgan, J.W., McDonnell, M.J., and McCarthy, M.A. 2005. Plant traits and local extinctions in natural grasslands along an urban-rural gradient. Journal of Ecology 93: 1203-1213.

Wilsey, B.J., Teaschner, T.B., Daneshgar, P.P., Isbell, F. I., and Polley, H.W. 2009. Biodiversity maintenance mechanisms differ between native and novel exoticdominated communities. Ecology Letters 12: 432-442.

Wilson, J.B., Peet, R.K., Dengler, J., and Pärtel, M. 2012. Plant species richness: the world records. Journal of Vegetation Science 23: 796-802. 


\title{
CURRICULUM VITAE
}

\author{
Sarah E. Atherton
}

\section{$\underline{\text { Education }}$}

University of Louisville, Louisville, Kentucky, 2010- Present

M.S. In Biological Sciences

Northern Kentucky University, Highland Heights, Kentucky, Fall 2006- Spring 2010

B.S. in Biology, Ecology, Evolution, Organismal Track

\section{$\underline{\text { Awards and Honors }}$}

Arts \& Sciences Graduate Student Union Grant, 2013

Environmental Protection Scholarship, 2007-Present

International Study Scholarship, 2008, 2009

Dean's List, 2007-2008

Black and Gold Scholarship, 2006-2010

\section{Research Experience}

Masters Research: Department of Biological Sciences, University of Louisville, 20112013, (Research Advisor: Dr. Perri K. Eason).

\section{Teaching Experience}

Supplemental Instruction Leader, Introduction to Chemistry, Northern Kentucky University, 2007-2009 